\title{
NORMA KESUSILAAN SEBAGAI BATASAN PENEMUAN HUKUM PROGRESIF PERKARA KESUSILAAN DI BANGKALAN MADURA
}

\author{
Hwian Christianto*
}

\author{
* Dosen Laboratorium Pidana Fakultas Hukum Universitas Surabaya, Surabaya \\ Korespondensi: hwall4jc@yahoo.co.id,hw_christianto@ubaya.ac.id \\ Naskah dikirim: 31 Januari 2016 \\ Naskah diterima untuk diterbitkan: 18 Maret 2016
}

\begin{abstract}
Society definitely have different conception to the norms especially Bangkalan citizen, Madura. Once social case happen, judge confronted to decide according to decency norms. The Bangkalan State Court have arranged decency norm as main basic to judge social case. The decision is accepted as a law product which appoint to justice. This thought is in line with progressive law-founding which underline the essence of society values conception as an exist law. The decision of Bangkalan State Court have kept the social that highly suspended by people in Bangkalan Madura.
\end{abstract}

Keywords: decency norm, judge, progressive law finding

\begin{abstract}
Abstrak
Tiap masyarakat memiliki pemahaman yang berbeda terhadap norma kesusilaan, tidak terkecuali masyarakat Bangkalan Madura. Setiap kali terjadi perkara kesusilaan, hakim ditantang untuk memberikan pertimbangan hukum sesuai norma kesusilaan yang diakui masyarakat. Hakim Pengadilan Negeri Bangkalan Madura ternyata telah menempatkan norma kesusilaan sebagai dasar utama dalam mengadili perkara kesusilaan. Hasil putusan hakim pun diterima masyarakat sebagai produk hukum yang mengedepankan keadilan. Pemikiran ini sejalan dengan penemuan hukum progresif yang menekankan pentingnya pemahaman nilai-nilai masyarakat sebagai hukum yang hidup. Sejauh ini putusan Pengadilan Negeri Bangkalan telah menampung nilai-nilai kesusilaan yang sangat dijunjung tinggi masyarakat Bangkalan Madura.
\end{abstract}

Kata kunci: norma kesusilaan, hakim, penemuan hukum progresif

\section{Pendahuluan}

Munculnya perkara kesusilaan yang semakin marak akhir-akhir ini menuntut sebuah pemahaman yang sangat mendalam tentang tatanan nilai yang pantas dan berlaku dalam sebuah masyarakat yang dikenal dengan norma 
kesusilaan. Bagaikan sebuah 'pagar' norma kesusilaan membatasi perilaku individu masyarakat agar tidak melampaui batas kesusilaan sebagai tindakan asusila. Fungsi kontrol dari adanya pelanggaran terhadap norma kesusilaan sebagaimana digariskan dalam politik hukum nasional secara sosiologis memang terletak di tangan masyarakat sebagai korban dari tindak pidana kesusilaan namun secara yuridis terdapat pada kekuasaan yudisiil.

Peran hakim dalam memeriksa dan mengadili perkara pidana kesusilaan tidak dapat dengan mudah dilakukan terutama pada masyarakat yang masih menjunjung tinggi adat sebagai sumber kesusilaan yang tertinggi. Sebagaimana berlaku dalam masyarakat Bangkalan Madura, nilai-nilai adat begitu menjiwai semua aspek kehidupan masyarakatnya terutama dalam hal kesusilaan. Masyarakat Madura menekankan "mon oreng riya benni bagusse, tape tatakramana, sanajjan bagus tapi tatakrama jube, ma'celep ka ate” (yang penting bukan ketampanan atau kecantikan namun tatakramanya). ${ }^{1}$ Pertimbangan baik dan tidak baik tidak lagi berada pada tataran keinginan namun pada prinsip hidup menyangkut kehormatan diri yang dijunjung tinggi. Berdasarkan hasil penelitian, Latief Wiyata menunjukkan bahwa gangguan terhadap istri menjadi penyebab utama dilakukannya carok dengan prosentase Perkara dari tahun 1990 sebanyak 21 Perkara (67,7\%), tahun 1991 sebanyak 23 Perkara (71, 9\%), tahun 1992 sebanyak 26 Perkara (72,2\%), tahun 1993 sebanyak 28 Perkara $(50,9 \%)$ dan tahun 1994 sebanyak 27 Perkara $(50,9 \%){ }^{2}$ Artinya peran hakim dalam memberikan putusan yang dapat menyerap nilainilai kesusilaan masyarakat Madura sangat dibutuhkan agar peristiwa carok tidak terulang. Pemahaman terhadap nilai-nilai yang berlaku di masyarakat ini sangat bersesuaian dengan ciri penemuan hukum progresif yang sangat penting dipahami oleh hakim. Penemuan hukum Progresif memiliki beberapa karakteristik diantaranya bersifat visioner (melihat kepentingan jangka panjang), berani melakukan terobosan mengikuti dinamika masyarakat, dan membawa kesejahteran kepada masyarakat. ${ }^{3}$ Hakim akan ditantang untuk menemukan hukum yang sesungguhnya hidup di masyarakat dan tidak terpaku pada Undang-Undang semata. Disinilah peran penting hakim sebagai pemberlaku hukum dan penegak hukum di tengah masyarakat.

\section{Perumusan Masalah}

Berdasarkan latar belakang di atas dapat diajukan beberapa permasalahan sebagai berikut:

\footnotetext{
${ }^{1}$ MH. Said Abdullah, 2011, "Menuju Madura Moderen Tanpa Kehilangan Identitas", (Jakarta: Taman Pustaka-SaidAbdullah Institute, 2011), hal. 132-133.

${ }^{2}$ Latief Wiyata, "Carok: Konflik Kekerasan dan Harga Diri Orang Madura”, (Yogyakarta: LKiS, 2006), hal. 4.

3 Ahmad Rifai, "Penemuan Hukum oleh Hakim dalam Perspektif Hukum Progresif", (Jakarta: Sinar Grafika, 2010), hal. 93.
} 
1. Apakah norma kesusilaan telah dijadikan dasar dalam penemuan hukum progresif oleh hakim di dalam penanganan perkara pidana kesusilaan di Pengadilan Negeri Bangkalan Madura?

2. Apakah hasil penemuan hukum progresif dalam putusan hakim Pengadilan Negeri Bangkalan Madura dapat dinilai telah menyerap nilai-nilai masyarakat Bangkalan Madura?

\section{Metode Penelitian}

Penelitian menggunakan metode penelitian yuridis normatif yang ditunjang dengan metode penelitian yuridis empiris. Penelitian ini dilakukan melalui studi pustaka atas peraturan perundang-undangan yang terkait dengan konsep norma kesusilaan, kemandirian hakim, penemuan hukum, aliran hukum progresif, doktrin-doktrin hukum yang berkaitan ditambah dengan beberapa data Putusan perkara kesusilaan Pengadilan Negeri Bangkalan Madura tahun 2008-2011.

Jabaran metode pendekatan dalam penelitian ini terdiri dari pendekatan perundang-undangan atau statute approach, pendekatan konseptual atau conceptual Approach, serta case study. Statute approach dan conceptual approach dijadikan landasan untuk menganalisis dan problem solving dari pertimbangan putusan hakim. Case study digunakan untuk memperhatikan pertimbangan hukum yang digunakan oleh hakim. Lokasi penelitian di Pengadilan Negeri Bangkalan dengan melibatkan 4 (empat) hakim PN Bangkalan hakim Pengadilan Negeri Madura yang pernah memutus perkara pidana kesusilaan.

Data primer dan sekunder dikumpulkan melalui metode inventarisasi, klasifikasi, dan sistematisasi bahan hukum. Untuk menganalisis, dilakukan deskriptif analisis atas bahan-bahan hukum yang diawali dengan menelaah bahan-bahan hukum primer dengan menggunakan metode deduksi. Pembahasan dari aspek normatif dikedepankan mengingat penelitian ini adalah penelitian hukum.

\section{Pembahasan}

\section{Penanganan dan Putusan Perkara Kesusilaan di Pengadilan Negeri Bangkalan Madura}

Sejak awal pendiri bangsa menekankan bahwa Negara Kesatuan Republik Indonesia didirikan untuk mewujudkan masyarakat Indonesia yang sejahtera. Pengertian Negara kesejahteraan yang dianut di Indonesia menuntut terpenuhinya kebutuhan materiil maupun spiritual. ${ }^{4}$ Kesejahteraan tidak akan

\footnotetext{
${ }^{4}$ Maleha Soemarsono, Negara Hukum Indonesia ditinjaun dari Sudut Teori Tujuan Negara, dalam "Jurnal Hukum dan Pembangunan“, Tahun ke-37 No. 2, April-Juni 2007, hal. 309.
} 
tercapai jika kebutuhan materi saja yan terpenuhi akan tetapi dilengkapi pula dengan kebutuhan akan keadilan, ketertiban, dan keamanan sebagai kebutuhan dasar setiap manusia di hadapan hukum. Berdasarkan pemahaman akan pentingnya pemenuhan kebutuhan untuk mendapatkan keadilan inilah peran lembaga yudisial sangat penting. Pengadilan Negeri sebagai lembaga kekuasaan kehakiman memiliki tugas utama dalam pencapaian tujuan tersebut yaitu menemukan fakta hukum dan dasar pertimbangan yang tepat dalam mengadili perkara yang dihadapinya (judex facti).

Tidak semua pengadilan negeri menangani jenis dan jumlah perkara dengan prosentase yang sama, terutama perkara kesusilaan. Pengadilan Negeri Bangkalan Madura memiliki keunikan dalam hal jenis perkara dan jumlah perkara kesusilaan yang ditangani. Frekuensi perkara kesusilaan yang ditangani tiap hakim Pengadilan Negeri Bangkalan tiap 3 (tiga) bulan sangat bervariasi mulai dari satu kali hingga lebih dari enam kali. ${ }^{5}$ Diagram 1. Frekuensi Penangan Perkara Kesusilaan dalam
3 bulan

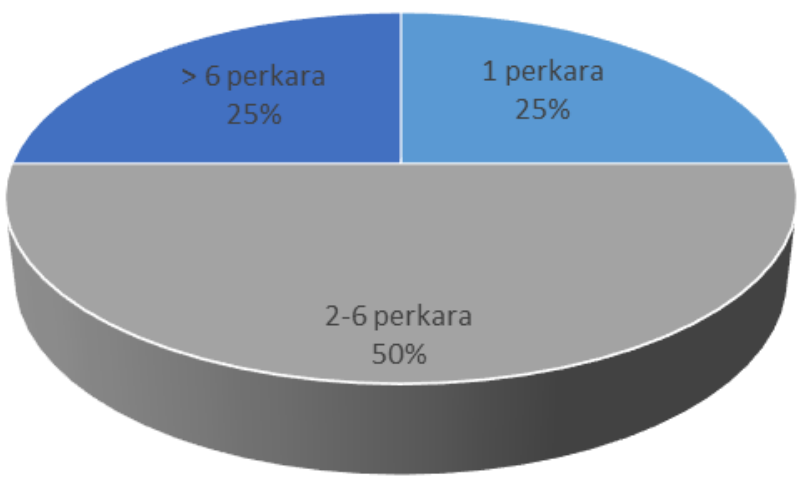

Berdasarkan Diagram 1 tampak kejahatan kesusilaan sering terjadi di masyakarat Bangkalan. Setiap hakim dapat dipastikan pernah menangani perkara kesusilaan tiap tiga bulan. Macam-macam perkara kesusilaan yang pernah diperiksa oleh Pengadilan Negeri Bangkalan dapat ditunjukkan melalui bagan berikut:

${ }^{5}$ Hasil Kuisioner Hakim Pengadilan Negeri Bangkalan Madura, Penelitian "Norma Kesusilaan sebagai Dasar Penemuan Hukum Progresif dalam Pertimbangan Putusan Hakim Pengadilan Negeri Bangkalan Madura", Universitas Surabaya, 2012. 


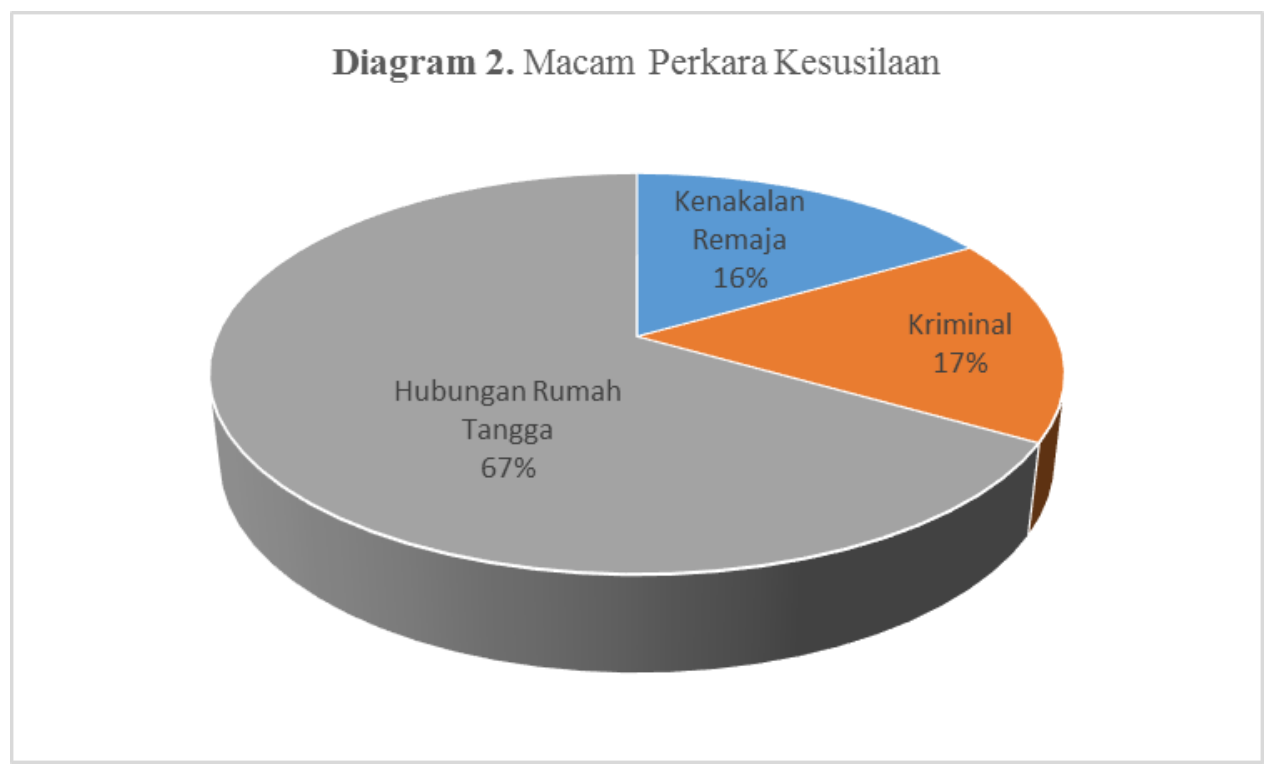

Hasil penelitian menunjukkan perkara kesusilaan yang terjadi berhubungan erat dengan masalah seksual. Artinya pemahaman kejahatan kesusilaan masih sangat sempit jika dibandingkan dengan ruang lingkup kejahatan kesusilaan menurut KUHP yang memasukkan tindakan yang dilarang oleh masyarakat dan melanggar rasa kesusilaan masyarakat sebagai bagian dari kejahatan kesusilaan. BAB XIV Buku II KUHP mengatur macam kejahatan kesusilaan terdiri dari kejahatan Overspel (Pasal 284 KUHP), Perkosaan (Pasal 285 KUHP), Persetubuhan dengan wanita dibawah umur (Pasal 286-288 KUHP), Percabulan (Pasal 289-294 KUHP), Penghubungan Percabulan (Pasal 295-297 KUHP), Pencegahan Kehamilan (Pasal 299 KUHP), dan Kejahatan terhadap kesopanan (Pasal 281-283 KUHP).

Penggunaan ketentuan hukum pidana di luar KUHP sering ditekankan pada kepentingan khusus pada setiap perkara yang diperiksa oleh hakim. Penentuan ketentuan hukum pidana apa yang akan dikenakan pada suatu Perkara kesusilaan juga mempertimbangkan keberadaan Undang-Undang baru dan mengatur lebih spesifik, sebagaimana tampak dalam Diagram 3 berikut: 


\section{Diagram 3. Ketentuan Hukum yang Digunakan bagi Perkara Pidana Kesusilaan}

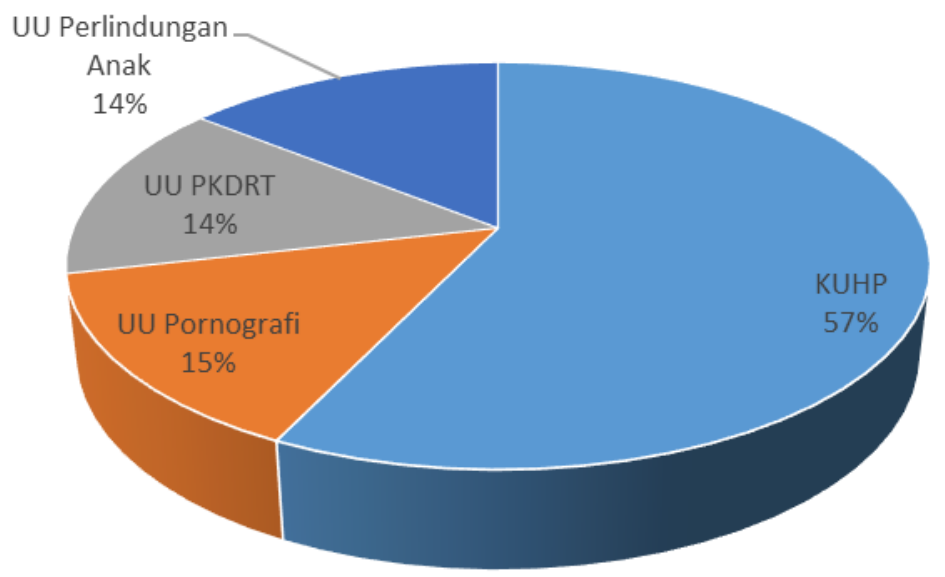

Hal menarik dari bagan di atas terkait penggunaan Undang-Undang Pornografi dan Undang-Undang Perlindungan Anak dalam mengadili perkara kesusilaan. Penggunaan kedua ketentuan hukum tersebut mengindikasikan bahwa hakim sangat memperhatikan perkembangan serta kekhususan perkara yang diperiksa, terutama dalam hal pelaku dan korban memiliki hubungan keluarga atau masih anak.

Salah satu Putusan Hakim Pengadilan Negeri Bangkalan Nomor 142/Pid.B/2009/ PN.Bkl. tanggal 28 September 2009 menjadi gambaran penanganan perkara kesusilaan Pengadilan Negeri Bangkalan. Perkara kesusilaan yang diperiksa menyangkut seorang anak berinisial Ma (17 tahun) diajak untuk bertemu Tf, kekasihnya di terminal Bus Jember lalu diajak menginap di rumah paman Tf beberapa hari dan selanjutnya diajak kawin siri. Ma terpaksa menerima permintaan tersebut karena ancaman Tf kepadanya. Tf pun melakukan persetubuhan dengan Ma dalam 5 malam atau sebanyak sepuluh kali hingga mereka pulang ke Bangkalan. Putusan Hakim pun menilai Tf bersalah melanggar Pasal 81 ayat (2) UUU No. 23 Tahun 2003 jo. Pasal 64 ayat (1) KUHP tentang Persetubuhan Anak secara Berlanjut. Hakim menganggap Tf sudah melakukan tipu muslihat sebagaimana tampak dalam tindakannya mengajak Ma menginap beberapa hari dan mengawininya secara siri untuk mempermudah melakukan hubungan seksual dengan Ma yang masih berusia 17 tahun.

Perkara Persetubuhan Anak secara Berlanjut juga mendapatkan penanganan sangat menarik dalam Putusan Pengadilan Negeri Bangkalan Nomor 234/Pid.B/2008/ PN.Bkl. tanggal 17 Nopember 2008. Pelaku MT mengajak NL untuk mengambil uang di Bank padahal MT mengajak NL ke sebuah rumah kosong dan menyetubuhi korban dengan ancaman. Persetubuhan tersebut dilakukan lagi saat MT mengajak NL menginap dirumahnya. Majelis hakim mempertimbangkan hal-hal yang paling memberatkan terletak pada MT 
yang melakukan tipu muslihat dengan tujuan melakukan hubungan badan dengan korban. Tidak adanya sikap berontak dari NL justru dipandang hakim bukan menunjukkan ketiadaan perlawanan/penolakan dari korban sehingga meyakinkan hakim memutus terdakwa bersalah. Ancaman MT sudah menunjukkan bahwa NL berada di bawah ancaman sehingga tidak mempunyai kuasa untuk menolak permintaan pelaku.

Sebuah perkara yang diputus Pengadilan Negeri Bangkalan Nomor 07/Pid.B.An/2009/PN.Bkl. Tanggal 23 Juni 2011 justru menunjukkan hal yang sangat berkebalikan dibandingkan dua contoh pertimbangan putusan hakim sebelumnya. Berawal dari SU mengajak HH yang masih berusia 4 tahun untuk bermain burung merpati di sebuah bukit namun SU justru menggunakan kesempatan ini untuk mengajak $\mathrm{HH}$ melakukan persetubuhan walaupun ditolak oleh HH. SU segera melucuti pakaian dan celana dalam $\mathrm{HH}$ dan melakukan penetrasi ke dalam alat kelamin HH. Korban pun merasa kesakitan sehingga membuat SU mencabut alat kelaminnya dan menggunakan tangannya pada alat kelamin HH. Majelis hakim menyatakan dakwaan primer Jaksa Penuntut Umum yang mendakwa tindakan perkosaan anak tidak terbukti karena SU dinilai tidak melakukan persetubuhan tetapi percabulan. Hal yang sangat mengejutkan jika dilihat bukti visum et repertum korban menunjukkan adanya robekan pada selaput dara korban akibat penetrasi benda tumpul. Walaupun demikian pertimbangan hakim ini sangat menarik karena hakim tidak hanya mempertimbangkan kepentingan anak yang menjadi korban melainkan juga kepentingan pelaku anak.

Beberapa contoh kasus tersebut menunjukkan adanya perbedaan cara penanganan dan pertimbangan hakim yang akhirnya berujung pada putusan yang berbeda pula. Kajian tersebut sangat menarik untuk melihat sampai sejauh mana hakim telah melakukan pemahaman nilai kesusilaan masyarakat Bangkalan Madura dan dapat dikatakan melakukan penemuan hukum.

\section{Norma Kesusilaan sebagai Dasar Penemuan Hukum Progresif di Pengadilan Negeri Bangkalan Madura}

Norma merupakan hasil kristalisasi nilai yang terbentuk dan disepakati masyarakat sehingga terkait erat demi terjaminnya ketertiban hidup. Pemahaman norma sangat berbeda dengan nilai dan hukum di sisi lainnya. Nilai merupakan "ukuran yang hidup" secara manunggal pada tiap manusia sebagai individu tidak bergantung pada ada atau tidaknya interaksi. ${ }^{6}$ Norma memiliki sifat mendasar tentang apa yang seharusnya dilakukan sebagai sesuatu yang terbaik (ought) sedangkan nilai memberi dasar tentang apa yang baik. Hanya tidak berarti pemahaman terhadap nilai menghilangkan keberlakuan norma. Perbedaan yang ada dalam pemahaman norma justru menciptakan adanya variasi pengakuan masyarakat terhadap kehidupan yang baik bukan menunjukkan ketiadaan norma dalam sebuah ketentuan hukum.

\footnotetext{
${ }^{6}$ Hwian Christianto, Norma Kesusilaan Sebagai Batasan Pornografi, dalam "Jurnal Hukum dan Pembangunan",Tahun ke-40 No. 1 Januari-Maret 2010, hal. 26.
} 
Norma menjadi inti pengaturan hukum sedangkan hukum memberikan bentuk bagi keberlakuan norma. Sundari menjelaskan hakikat hukum sebagai “... suatu sistem norma karya manusia yang penuh kekurangan karena tergantung pada waktu dan tempat sehingga sifatnya tidak selesai dan tidak dapat selesai". ${ }^{7}$ Tidak salah jika hakim harus melakukan penggalian terhadap norma yang hidup di masyarakat untuk memberlakukan hukum yang dikehendaki masyarakat. Suliantoro menjelaskan keterkaitan hukum dan nilai sebagai berikut: "Hukum yang baik adalah hukum yang mampu menciptakan kondisi dimana potensi diri maupun masyarakat dapat berkembang secara optimal. Manusia menciptakan hukum bagi dirinya sendiri agar kehidupan semakin berbudaya". 8 Artinya, hubungan antara nilai, norma, dan hukum kesusilaan merupakan wujud dari kebutuhan dasar manusia untuk bereksistensi sebagai manusia yang beradab.

Norma kesusilaan semacam ini juga terbentuk dalam masyarakat Bangkalan Madura. Norma kesusilaan menjadi ukuran yang penting dalam menilai tindakan memenuhi kriteria kesusilaan (tindakan susila) ataukah tindakan tidak memenuhi kriteria kesusilaan (tindakan asusila). Masyarakat Bangkalan sendiri memandang norma kesusilaan sebagai bagian yang integral dalam kehidupan masyarakatnya bahkan sebagai ukuran kehormatan sebuah keluarga di tengah masyarakatnya. Hal tersebut tampak dari ungkapan "madu ben dara" (madu dan darah) yang berarti orang Madura jika diperlakukan sesuai nilai kesusilaan maka ia akan melakukan hal itu kepada orang tersebut begitu pula sebaliknya (ja'nabi'oreng mon aba'na e tobi'sake'). ${ }^{9}$ Posisi norma kesusilaan yang sedemikian penting tersebut sudah layak dijadikan ukuran terpenuhinya kesusilaan sebagaimana diatur dalam KUHP.

Pemahaman akan nilai kesusilaan menunjukkan adanya sebuah pengakuan akan keberlakuan norma kesusilaan sebagai batasan dari tindak pidana kesusilaan sesuai pasal 1 angka 1 UU No. 44 Tahun 2008. Produk legislasi tersebut dinilai responsif dalam memahami kebutuhan masyarakat yang berbeda-beda ${ }^{10}$ serta tidak diskriminatif ${ }^{11}$ dengan menetapkan norma kesusilaan sebagai ukuran tindak pidana pornografi. Masyarakat Madura dengan karakteristik budaya yang berbeda dengan masyarakat lain memiliki penghayatan berbeda terhadap nilai-nilai kesusilaan. Said Abdullah menegaskan ciri khas penghayatan norma kesusilaan bagi orang Madura

${ }^{7}$ E. Sundari, Aspek Ilmiah Metode Penemuan Hukum, dalam "Jurnal Justitia Et Pax“, Tahun 27 No. 1 Juni 2007, hal. 58.

${ }^{8}$ B. Wibowo Suliantoro, Dialektika Hukum dan Agama dalam Pembangunan Hukum Nasional di Indonesia: Kajian Moral Politik Hukum, dalam "Jurnal Justitia Et Pax", Tahun 27 No.1 Juni 2007, hal. 35 .

${ }^{9}$ MH. Said Abdullah, Loc.cit.

${ }^{10}$ Muchamad Ichsan, Landasan Kebijakan Legislatif Pembangunan Hukum Pidana Indonesia, dalam “Jurnal Ilmu Hukum", Tahun ke 10 No. 1 Maret 2007, hal. 108.

${ }^{11}$ Muchsin, Tindak Pidana Pornografi Menurut Undang-Undang Nomor 44 Tahun 2008 dalam "Varia Peradilan", Tahun ke XXIV No. 280 Maret 2009, hal. 13. 
dengan ungkapan "pa tao ajalan jalana jalane, pa tao neng ngenneng, pa tao a ca ca (yang menjadi kewajiban harus dilaksanakan sesuai dengan aturan) artinya orang harus tahu saatnya diam, harus tahu saatnya bicara. ${ }^{12}$ Pemahaman tersebut memang bisa saja dipahami berbeda oleh masyarakat lainnya walaupun pada intinya menjunjung tinggi nilai kesusilaan. Selain pemaknaan norma kesusilaan yang begitu berbeda-beda, pemahaman akan sejauh mana norma kesusilaan itu berlaku juga mengalami perkembangan dari waktu ke waktu. Perbedaan penilaian tersebut sangat menarik untuk dikaji secara mendalam terutama ketika hakim menangani perkara kesusilaan.

Penempatan norma kesusilaan sebagai dasar penanganan perkara kesusilaan membuka paradigma baru bagi hakim untuk tidak melulu mengandalkan ketentuan hukum. Hukum tidak lagi dimaknai ketentuan hukum tertulis tetapi norma yang berlaku berdasarkan prinsip keadilan. Hukum sangat luas ruang lingkupnya karena keberadaan hukum mengikuti setiap aktivitas manusia dalam kehidupan bermasyarakat sehingga hakim tidak boleh ketiggalan tetapi mengikuti dan menggali nilai hukum demi terciptanya keadilan. ${ }^{13}$ Artinya hakim bertanggungjawab bukan hanya pada diri sendiri atau masyarakat tetapi pada Tuhan Yang Maha Esa sehingga proses mengadili dilakukan dengan hati nurani.

Pemahaman hukum yang tidak kaku tetapi fleksibel dengan tetap mendasarkan diri pada norma yang berlaku di masyarakat sangat sesuai dengan paradigma hukum progresif yang mendasarkan diri pada nilai masyarakat. Nilai-nilai masyarakat akan menjadi sebuah kearifan lokal (local wisdom) yang berkontribusi besar dalam pembangunan hukum karena di dalamnya terkandung prinsip keteraturan dan keseimbangan yang luhur. ${ }^{14}$ Asumsi dasar yang dipegang oleh hakim saat menangani perkara adalah hukum yang terkait dengan perkara tersebut sudah ada tetapi belum ditemukan.

Hukum progresif secara singkat dimaknai sebagai paradigma hukum yang mengikuti atau memahami nilai-nilai hukum di masyarakat. Peran penting hukum progresif dalam proses mengadili yaitu Pertama, Hukum Progresif merupakan Hukum yang Membebaskan karena mampu melakukan terobosan terhadap legisme hukum dan mengedepankan rasa keadilan, Kedua, Solusi atau Startegi Jalan Tengah karena mengelaborasi hukum tertulis dan hukum tidak tertulis, dan Ketiga, Gerakan Pembebasan dalam tahap pemahaman dasar hukum karena hukum menjadi sebuah alat untuk mengakomodasi nilai masyarakat dengan tetap mendasarkan diri pada nilai Pancasila. ${ }^{15}$ Paradigma tersebut pada gilirannya mempengaruhi pemahaman hakim terhadap apa yang

\footnotetext{
${ }^{12}$ MH. Said Abdullah, Loc.cit.

${ }^{13}$ Harifin A. Tumpa, Apa yang Diharapkan Masyarakat dari Seorang Hakim, dalam "Varia Peradilan”, Tahun ke 298, no. XXV, September 2010, hal. 6.

${ }^{14}$ D.Y. Witanto, Konsepsi 'Local Wisdom' dalam Upaya Pembentukan Kesadaran Hukum, dalam "Varia Peradilan", Tahun XXVII No. 314 Januari 2012, hal. 77-78.

${ }^{15}$ Hwian Christianto, Penafsiran Hukum Progresif dalam Perkara Pidana, dalam "Jurnal Mimbar Hukum”, Tahun 23 No. 3 Oktober 2011, hal. 483-485.
} 
dimaksud dengan penemuan hukum pada saat memberikan pertimbangan putusan.

Sejauh ini penemuan hukum hanya dimaknai sebagai kegiatan mendapatkan hukum melalui proses penafsiran yang dilakukan oleh hakim saat menghadapi kekosongan hukum (rechtsvacuum). Kebebasan yang dimiliki hakim pidana memang tidak seluas hakim perdata karena hakim pidana dibatasi sistem tertutup dari hukum pidana sehingga tidak dapat menciptakan delik baru ataupun sanksi baru di luar Undang-Undang. ${ }^{16}$ Asas legalitas menekankan moneat lex, pusquiam feriat, undang-undang harus memberikan peringatan terlebih dahulu sebelum merealisasikan ancaman yang terkandung di dalamnya. ${ }^{17}$ Pemahaman tersebut sepintas tidak sesuai dengan Pasal 1 angka 1 Undang-Undang Nomor 48 Tahun 2009 yang menekankan penegakan hukum dan keadilan berdasarkan Pancasila dan UUD 1945. Artinya, bukan hanya kepastian hukum yang ditonjolkan tetapi aspek keadilan sebagai aspek penyeimbang. Tujuan kekuasaan kehakiman tersebut diperjelas melalui Pasal 5 ayat (1) Undang-Undang a quo yang menitikberatkan kewajiban hakim untuk lebih menggali nilai-nilai hukum yang hidup di masyarakat.

Pemahaman tersebut pada perkembangannya berdampak pada pemahaman asas legalitas menjadi pemahaman asas legalitas secara materiil. Pemahaman "lex" dalam adagium nullum delictum nulla poena sine praevia lege (lex) poenali menjadi lebih dalam karena menyangkut ketentuan hukum tidak tertulis (nilai-nilai hukum di masyarakat/sine ius). ${ }^{18}$ Oleh karena itu penemuan hukum pun sebenarnya terbuka dilakukan oleh hakim saat menghadapi perkara kesusilaan.

Hal yang menarik dari hasil penjelasan hakim PN Bangkalan terhadap kejelasan norma hukum yang mengatur kejahatan kesusilaan ternyata menunjukkan hasil berimbang 50\% menyatakan sudah sangat jelas dan memadai dan $50 \%$ menyatakan belum memadai. Dasar argumentasi pertama disebabkan begitu banyaknya ketentuan hukum positif yang mengatur tentang kejahatan kesusilaan, mulai KUHP, Undang-Undang Perlindungan Anak, Undang-Undang Pornografi, Undang-Undang Penghapusan Kekerasan Dalam Rumah Tangga, dan lain-lain walaupun sebenarnya dari ketentuan hukum yang ada masih dibutuhkan langkah pemahaman hukum selanjutnya.

Pendapat yang menarik justru muncul dari salah seorang reponden yang mencoba menampilkan ketidakjelasan ketentuan hukum kesusilaan dibalik kejelasan rumusan ketentuan hukum yang ada. ${ }^{19}$ Hal penting yang harus

16 Elisabeth Nurhaini Butarbutar, Kebebasan Hakim Perdata dalam Penemuan Hukum dan Antinomi dalam Penerapannya, dalam “Jurnal Mimbar Hukum”, Tahun 23 No.1 Februari 2011, hal. 63.

17 Eddy O.S. Hiarej, Pemikiran Remmelinjk Mengenai Asas Legalitas dalam "Jentera Jurnal Hukum", Tahun ke-16 No. IV April-Juni 2007, hal. 127.

18 Hwian Christianto, Pembaharuan Makna Asas Legalitas, dalam "Jurnal Hukum dan Pembangunan", Tahun Ke-39 No. 3 Juli-September 2009, hal. 364-365. 
dilakukan oleh hakim dalam memberikan putusan dalam perkara kesusilaan adalah pemahaman perasaan susila dari masyarakat di suatu daerah. Terjadinya sebuah perkara kesusilaan tidak menunjukkan adanya perubahan norma kesusilaan yang dianut sebuah masyarakat sebaliknya merupakan tanda keteraturan sejati dari norma kesusilaan. Tahap penanganan perkara kesusilaan menjadi batu uji sejauh mana norma kesusilaan dijadikan standar penilaian. Pendekatan inilah yang disebut sebagai Chaos Theory of Law yang memandang ketidakteraturan (terjadinya kejahatan kesusilaan) sebagai bagian kecil dari sebuah sistem yang teratur secara holistik. ${ }^{20}$ Hakim harus memandang norma kesusilaan sebagai keteraturan yang harus dipertahankan karena memang selalu demikian adanya.

Pemahaman Chaos Theory of Law tersebut ternyata memiliki titik temu dengan konsep penemuan hukum progresif. Pemahaman hukum dilihat sebagai sarana bagi tercapainya kebutuhan manusia yang terus menerus bergerak dalam kestabilan. Satjipto Rahadjo menegaskan "sistem hukum haruslah sistem yang logis, tetap dan bersifat tertutup yang diperoleh atas dasar logika, tanpa dan bersifat tertutup yang diperoleh atas dasar logika, tanpa mempertimbangkan aspek sosial, politik, moral maupun etik."21 Ahmad Rifai menegaskan kajian hukum progresif menempatkan manusia sebagai sentralitas utama dan mengandung moralitas kemanusiaan. ${ }^{22}$ Progresifitas dari sebuah pemikiran hukum dapat dilihat dari kemauan diri penegak hukum untuk membuka diri pada kemauan masyarakat yang tercermin dalam nilai-nilai kesusilaan yang hidup dan berkembang secara unik di tiap masyarakat.

Pemahaman arti penting nilai kesusilaan sebagaimana tercermin dalam norma kesusilaan tidak dapat dimiliki oleh hakim secara otomatis. Hakim akan melakukan berbagai macam langkah untuk melakukan pemahaman terhadap norma kesusilaan yang ada di suatu masyarakat. Seperti yang dilakukan hakim PN Bangkalan, saat diperhadapkan pada ketentuan hukum yang belum jelas untuk digunakan sebagai dasar mengadili beberapa tindakan yang selalu dilakukan adalah:

\footnotetext{
19 Hasil Kuisioner Hakim Pengadilan Negeri Bangkalan Madura, Penelitian Norma Kesusilaan sebagai Dasar Penemuan Hukum Progresif dalam Pertimbangan Putusan Hakim Pengadilan Negeri Bangkalan Madura, Universitas Surabaya, 2012.

20 Sudjito, Chaos Theory of Law: Penjelasan atas Keteraturan dan Ketidakteraturan dalam Hukum, dalam "Jurnal Mimbar Hukum”, Tahun ke-18 No.2 Juni 2006, hal. 164.

${ }^{21}$ Satjipto Rahardjo, “Membedah Hukum Progresif”, (Jakarta: Kompas, 2007), hal. 162.

${ }^{22}$ Ahmad Rifai, Loc.cit, hal. 45.
} 


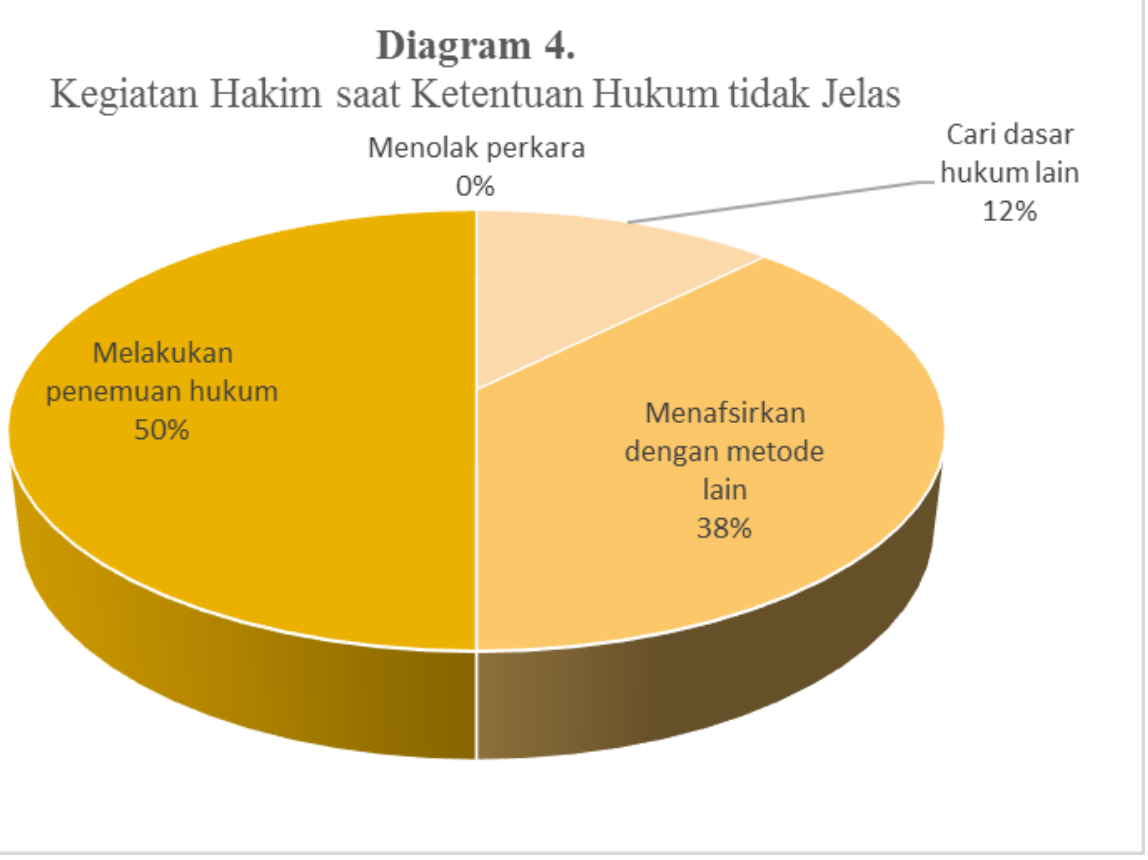

Kesadaran penegak hukum terhadap kelemahan ketentuan hukum merupakan bagian kecil dari proses pemahaman dalam lingkaran hermeneutika (hermeneuticsche Zirkel) untuk sampai pada kesimpulan yang tepat dengan melibatkan nilai-nilai kesusilaan yang berlaku. ${ }^{23}$ Disini hermeneutika hukum berkontribusi besar dalam memberikan jalan bagi hakim menafsirkan ketentuan hukum sebagai dasar pertimbangan sekaligus interpretasi peristiwa dan fakta ${ }^{24}$ demi terbentuknya sebuah putusan.

Penafsiran dengan menggunakan metode penafsiran pada dasarnya dapat dipandang sebagai bagian upaya hakim melakukan penemuan hukum. Penafsiran dilakukan dengan kesadaran bahwa tidak pernah ada peristiwa hukum tepat seperti lukisan dalam Undang-Undang, tuntutan keadilan, keterbatasan makna bahasa, serta pengaruh perkembangan masyarakat. ${ }^{25}$ Sebagai contoh penafsiran ekstensif yang lebih mengedepankan perkembangan makna dalam ketentuan hukum di masyarakat tetapi tetap mendasarkan diri pada maksud dan ruang lingkup Undang-Undang. Selain memperluas makna gramatikal dari suatu aturan hukum positif, hakim melalui penafsiran ekstensif juga memberikan pemaknaan terhadap aturan hukum yang telah di perluas itu sebagai suatu makna yang di terima dan di akui berlaku di masyarakat ${ }^{26}$.

${ }^{23}$ B. Arief Sidharta, Struktur Ilmu Hukum Indonesia, dalam "Jurnal Refleksi Hukum", Tahun ketanpa nomor, Oktober 2008, hal. 119-120.

24 Ahmad Zaenal Fanani, Hermeneutika Hukum sebagai Metode Penemuan Hukum dalam Putusan Hakim, dalam "Varia Peradilan", Tahun ke-XXC No. 297 Agustus 2010, hal. 61.

${ }^{25}$ Bagir Manan, Beberapa Catatan tentang Penafsiran, dalam "Varia Peradilan”, Tahun Ke-XXIV No. 285 Agustus 2009, hal. 10-11. 
Hakim tidak terjebak pada legalistik-positivistik tetapi melakukan penemuan hukum.

Hakim Pengadilan Negeri Bangkalan mengenal penemuan hukum sebagai suatu cara untuk mendapatkan dasar hukum yang dapat digunakan sebagai dasar mengadili ketika ketentuan hukum yang ada belum jelas. Ukuran dari jelas atau tidaknya ketentuan hukum yang ada lebih digantungkan pada mudah atau tidaknya hakim mengkaji setiap unsur dari rumusan perbuatan yang diatur dalam ketentuan hukum pidana dengan unsur perbuatan yang terdapat dalam fakta hukum suatu peristiwa. Hakim PN Bangkalan memaparkan alasan dilakukannya penemuan hukum karena kekosongan hukum dan ketentuan hukum yang ada tidak jelas. Artinya, hakim PN Bangkalan menganggap bahwa penemuan hukum merupakan langkah akhir saat ketentuan hukum yang ada belum dapat digunakan secara tepat untuk mengadili suatu perkara.

Penemuan hukum sebagai langkah akhir cenderung menempatkan penemuan hukum sebagai suatu cara istimewa bagi hakim untuk membuat hukum saat hukum yang berlaku tidak mengatur atau tidak jelas. Hal tersebut justru menunjukkan pemahaman hakim masih terjebak dalam legisme hukum di satu sisi terpisah dari kebebasan hakim di sisi lainnya. Penilaian hakim terhadap ketentuan hukum jelas atau tidak jelas lebih dilatarbelakangi oleh belum tepatnya unsur perbuatan konkrit pada salah satu unsur dari rumusan ketentuan hukum. Posisi tersebut akan membuat hakim terjebak pada legisme aturan sebagai norma hukum tertinggi padahal di sisi lain hakim memiliki kewajiban untuk mengkaji nilai-nilai hukum yang hidup di masyarakat.

\section{Penemuan Hukum Progresif dan Penyerapan Nilai-nilai Masyarakat Bangkalan Madura}

Kajian putusan hakim dapat dilakukan melalui berbagai macam cara, baik proses pengadilan berlangsung yang dikaitkan dengan putusan maupun terhadap materi pertimbangan putusan hakim sebelum sampai pada putusan (ratio decidendi). Pemahaman secara mendalam terhadap metode penemuan hukum apa yang digunakan oleh hakim dapat terlihat dengan jelas dalam pertimbangan putusan. Termasuk untuk mengetahui sejauhmana hakim melibatkan nilai-nilai yang hidup di masyarakat sebagai tanda diterapkannya penemuan hukum progresif.

Sebenarnya pemahaman terhadap penemuan hukum progresif harus dilakukan secara konsep mengingat teori hukum yang memberi landasan bagi pemberlakuan ketentuan hukum yang ada. Teori hukum tidak hanya memberikan dasar tetapi cara pandangan (wawasan) tentang hakikat dan tujuan pemberlakuan ketentuan hukum agar tidak salah arah. ${ }^{27}$ Beberapa ketentuan

${ }^{26}$ Hwian Christianto, Batasan dan Perkembangan Penafsiran Ekstensif, dalam "Jurnal Pamator", Tahun ke 3 No. 2 Oktober 2010, hal. 112.

${ }^{27}$ E. Sundari, Manfaat Mempelajari Teori Hukum, dalam "Jurnal Justitia Et Pax", Tahun ke-27 No. 2 Desember 2007, hal. 180. 
hukum seperti Pasal 5 ayat (1) dan Pasal 10 ayat (1) Undang-Undang Nomor 48 Tahun 2009 menegaskan hakim harus melakukan penemuan hukum dengan melakukan penggalian terhadap nilai-nilai hukum dan rasa keadilan masyarakat. Disinilah putusan hakim memiliki kualitas mahkota karena sanggup mengakomodasi das sein serta das sollen $^{28}$ dari suatu perkara yang ditanganinya. Hakim tidak boleh menempatkan penemuan hukum sebagai langkah terakhir saat terjadi kekosongan hukum tetapi menempatkannya sejak awal. Selain itu, kedua ketentuan hukum tersebut ingin menegaskan kegiatan penggalian nilai-nilai masyarakat bukanlah sebuah metode melainkan paradigma dalam menjalankan kekuasaan kehakiman. Terkait dengan pemaham-an terhadap arti penting penemuan hukum sendiri, hakim PN Bangkalan cenderung menggunakan metode penemuan hukum ketika terjadi kekosongan hukum dan ketika menghadapi perkara yang tidak jelas.

\section{Diagram 5. Alasan melakukan Penemuan Hukum}

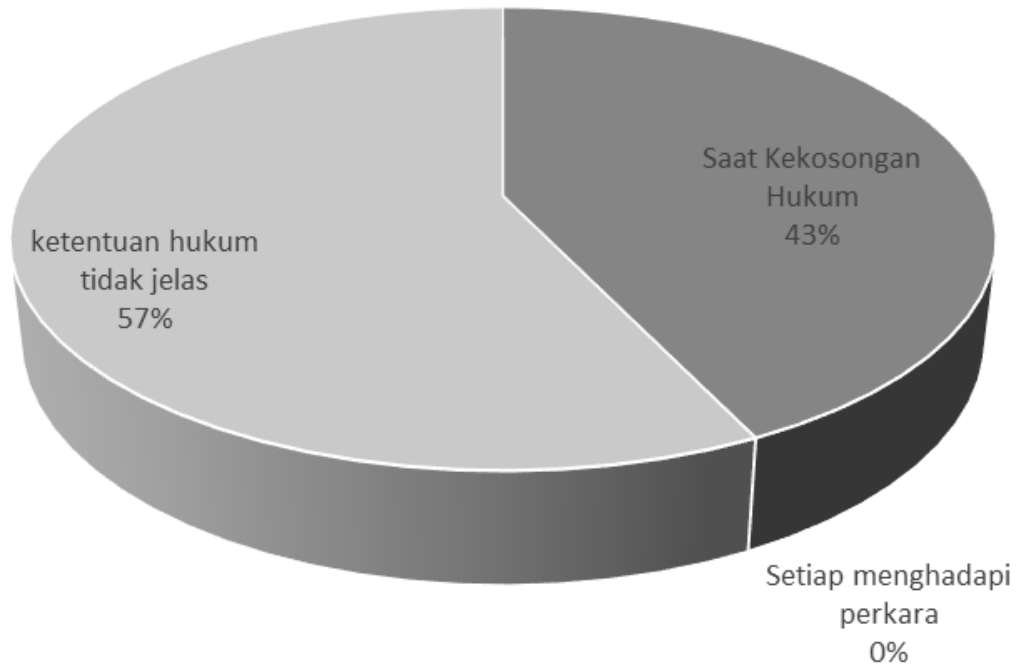

Hakim masih memiliki pandangan bahwa penemuan hukum merupakan langkah akhir yang dapat dilakukan jika terdapat dua kondisi yaitu kekosongan hukum dan ketentuan hukum yang ada tidak jelas untuk dapat diterapkan. Kondisi tersebut secara sepintas memang tidak mempunyai dampak berarti bagi proses mengadili akan tetapi sangat berdampak besar pada penegakan hukum. Terkait dengan pengenalan akan metode penemuan hukum progresif $50 \%$ respoden memahami model penemuan hukum progresif. Hal tersebut didasarkan pada pemahaman bahwa hukum sangat luas dan kompleks ${ }^{29}$ mengingat kehidupan masyarakat begitu rumit dan membutuhkan pemahaman

28 A. Mukti Arto, Putusan Yang Berkulitas Mahkota bagi Pencari Keadilan, dalam "Varia Peradilan”,Tahun ke XXV No. 296 Juli 2010, hal. 23.

${ }^{29}$ Harifin A. Tumpa, Loc.cit. 
yang lengkap. Hal yang perlu diwaspadai dalam penggunaan penemuan hukum bukan berarti hakim diberikan kebebasan yang sebebas-bebasnya dalam membentuk hukum karena jika demikian maka hukum tersebut berasal dari hakim sehingga terjadilah kesewenang-wenangan dalam mengadili.

Disinilah peran hakim yang sesungguhnya sebagai pencari dasar hukum yang jelas demi menegakkan hukum dan keadilan. Seorang hakim tidak boleh memaksakan norma hukum yang sudah tidak relevan karena hal itu sama artinya dengan mewujudkan suatu ketidakadilan (summum ius summa iniura $)^{30}$. Seorang hakim yang mulai memeriksa perkara yang dihadapkan kepadanya akan segera memandang perkara tersebut dari yuridis-normatif dan kondisi/situasi yang menyertai terjadinya perkara. Selanjutnya dalam proses pertimbangan yang tepat, seorang hakim dapat menjadi filsuf hukum karena ia tidak hanya mampu membaca teks dan memahami perkara kesusilaan tetapi menghasilkan pertimbangan filosofis padat makna melalui produk hukum, yurisprudensi. ${ }^{31}$ Kemampuan dan kesediaan hakim untuk melakukan penemuan hukum melalui nilai hukum dan rasa keadilan masyarakat akan memperkuat kekuasaan kehakiman yang telah melaksanakan fungsinya.

Penemuan hukum progresif menekankan pentingnya hukum yang hidup dalam nilai-nilai yang berlaku dalam masyarakat sebagai dasar penegakan hukum yang tepat. Hakim dalam kegiatan penemuan hukum secara progresif akan menyeleraskan ketentuan hukum pidana kesusilaan dengan pemahaman nilai kesusilaan sehingga menghadirkannya sebagai dasar pertimbangan yang tepat. Penyerapan nilai-nilai kesusilaan ini akan sangat tampak dalam pertimbangan hakim dalam memberikan makna terhadap salah satu atau beberapa unsur dalam ketentuan hukum pidana. Hakim Pengadilan Negeri Bangkalan Madura dalam beberapa pertimbangan putusan telah menyerap nilai-nilai kesusilaan yang ada di masyarakat Bangkalan.

Putusan Hakim Pengadilan Negeri Bangkalan Nomor 142/Pid.B/2009/ PN.Bkl. tanggal 28 September 2009 menjadi sebuah contoh penemuan hukum progresif yang dilakukan oleh hakim. Perkara kesusilaan tentang seorang anak berinisial Ma (17 tahun) yang menjadi korban tindakan perkosaan pelaku, Tf seperti telah dijelaskan sebelumnya menunjukkan kemampuan hakim dalam menyerap nilai-nilai kesusilaan yang berlaku di Bangkalan. Adanya rangkaian kebohongan, tipu muslihat, atau pembujukan (Rumusan pasal 81 ayat (2) UU No. 23 Tahun 2002) dengan tujuan mempermudah dilakukannya persetubuhan dengan anak ternyata diberikan pemahaman secara berbeda oleh majelis hakim. Pertimbangan hakim melihat bahwa tindakan Tf yang mengajak bertemu di terminal bus, mengajaknya untuk tidur di rumah saudara Tf, dan melakukan kawin siri merupakan rangkaian perbuatan tipu muslihat yang sudah

30 H.M. Abdi Koro, Penguasaan Hukum Formal dan Materiil Wajib Dimiliki untuk Pengembangan Kemampuan Hakim (Mastery of Legal Formal and Material Must Be Owned for the Development of the Ability of Judges), dalam Varia Peradilan, Tahun ke XXVII No. 319 Juni 2012, hal. 46

31 H.M. Fauzan, Pesan Keadilan di Balik Teks Hukum yang Terlupakan: Refleksi atas Kegelisahan Prof. Asikin, dalam Varia Peradilan, Tahun ke-XXVI No.299 Oktober 2010, hal. 44 
direncanakan sebelumnya. Pertimbangan hakim tersebut bukan hanya mengedepankan kepentingan anak akan tetapi harga diri (martabat) keluarga korban yang menganggap kejadian tersebut sebagai aib. Hal tersebut sesuai dengan nilai kesusilaan Madura berbunyi "lebih bagus apote tolang etembang apote mata (lebih baik putih tulang daripada malu tidak dapat mempertahankan diri) yang menunjukkan harga diri orang Madura terletak pada ego, wanita, agama, serta tanah air. ${ }^{32}$ Terobosan hakim justru tampak jelas ketika menganggap dilakukannya kawin siri sebagai bagian dari tipu mulihat pelaku mengingat saksi dari pihak korban tidak ada.

Sekali lagi, pertimbangan hakim lebih menitikberatkan pada kepentingan anak melalui penafsiran sistematis dan teleologis terhadap Pasal 81 ayat (2) UU RI No. 23 Tahun 2002 jo pasal 64 ayat (1) KUHP tentang Persetubuhan terhadap Anak secara Berlanjut sehingga perbuatan Tf sekalipun disetujui oleh Ma tidak dapat dikatakan dilakukan atas dasar suka sama suka. Hakim sudah mengedepankan nilai-nilai kesusilaan yang berlaku saat ini terutama dalam hal mempertimbangkan rasa malu yang ditanggung korban dan keluarga korban atas perbuatan pelaku yang walaupun masih berusia anak-anak tetap harus mendapatkan hukuman.

Pertimbangan Putusan Pengadilan Negeri Bangkalan No.123/Pid.B/2010/PN.Bkl. tanggal 11 Agustus 2010 juga menunjukkan paradigma hakim yang seimbang dalam menjatuhkan putusan. Perkara yang berawal dari seorang anak melarikan diri karena marah dengan orang tuanya namun korban bertemu dengan pelaku dan diajak untuk menginap di rumahnya. Kesempatan tersebut ternyata dimanfaatkan oleh pelaku untuk melakukan persetubuhan dengan korban. Pertimbangan hakim PN Bangkalan atas Perkara sebagai berikut:

Menimbang, bahwa dalam perkara ini Majelis telah melihat fakta di persidangan bahwa kesalahan ini tidak semata-mata kesalahan dari terdakwa namun juga kesalahan dari orang tua terdakwa yang tidak memperbolehkan saksi korban pulang/ masuk rumah dan juga kesalahan dari saksi korban yang dengan mudah mau ditawari bermalam di rumah terdakwa dan pada saat akan disetubuhi saksi korban tidak berontak, tidak keberatan hal ini karena pada waktu berada di rumah terdakwa ada orang tua terdakwa.

Berdasarkan pertimbangan yang meringankan tersebut tampak nilai-nilai kesusilaan yang dianut oleh hakim, dimana hakim berpendapat bahwa kesalahan tidak hanya berada pada pihak terdakwa namun juga pihak orang tua saksi korban dan saksi korban sendiri. Hal tersebut sangat bersesuaian dengan nilai kesusilaan yang dianut masyarakat Madura yang menganggap perlindungan pada anak perempuan sebagai tanggung jawab orang tua (Taneyan Lajang) sehingga jika terjadi apa-apa pada anak akibat kesalahan

\footnotetext{
${ }^{32}$ MH. Said Abdullah, Loc.cit., hal. 134.
} 
orang tua, mereka ikut bertanggungjawab. Orang tua saksi korban yang tidak mengizinkan saksi korban untuk pulang/masuk rumah, juga ikut bersalah akan terjadinya tindak pidana ini. Pemahaman dari sisi teori penemuan hukum, pertimbangan hakim yang demikian ini termasuk dalam aliran penemuan hukum progresif karena tidak hanya mendasarkan diri pada hukum tertulis melainkan kondisi masyarakat Bangkalan.

Nilai kesusilaan ini juga tampak pada pertimbangan tersebut dalam hal bahwa hakim juga mempersalahkan saksi korban, karena sebagai anak perempuan seharusnya tidak begitu saja ikut dengan seorang laki-laki, apalagi untuk diajak ikut bermalam di rumahnya. Terutama dengan fakta bahwa saksi korban tersebut membantah orang tuanya, yang menyebabkan ia tidak boleh masuk rumah. Pertimbangan tersebut pada dasarnya tidak memenuhi kebutuhan korban, karena esensi dari Undang Undang Perlindungan Anak adalah perlindungan khusus bagi anak sebagai generasi penerus bangsa.

Nilai yang dianut oleh hakim tersebut memang sedikit banyak bertentangan dengan esensi dari Undang-Undang Perlindungan anak yang melihat anak sebagai korban. Sedangkan pada pertimbangan tersebut juga dinyatakan bahwa saksi korban dengan mudah menyetujui saat ditawari tidur untuk di rumah terdakwa, serta tidak berontak dan tidak keberatan saat disetubuhi, pernyataan ini sangat menyudutkan saksi korban dengan anggapan bahwa saksi korban seakan-akan menyetujui perbuatan tersebut dilakukan terhadapnya, dengan tidak mengindahkan fakta di persidangan bahwa terdakwa merupakan seorang pria yang pada saat dilakukannya persetubuhan itu menahan tubuh saksi korban, dan melewatkan kemungkinan apabila saat itu saksi korban terlalu takut untuk teriak dan tidak dapat berontak. Fakta lain yang ada adalah saksi korban setuju untuk tidur di rumah terdakwa karena terdakwa adalah anggota keluarga yaitu saudara sepupu. Sedangkan di rumah terdakwa tinggal orang tua terdakwa dan adik dari terdakwa, sehingga saksi korban merasa yakin dan percaya terhadap terdakwa.

Kasus selanjutnya, perkara Persetubuhan Anak secara Berlanjut juga mendapatkan pertimbangan putusan yang sangat menarik dalam Putusan Pengadilan Negeri Bangkalan Nomor 234/Pid.B/2008/ PN.Bkl. tanggal 17 Nopember 2008. Pelaku MT mengajak NL untuk mengambil uang di Bank padahal ternyata MT mengajak NL ke sebuah rumah kosong dan menyetubuhi korban dengan ancaman. Persetubuhan tersebut dilakukan lagi saat MT mengajak NL menginap dirumahnya. Majelis hakim memper-timbangkan halhal yang paling memberatkan terletak pada MT yang melakukan tipu muslihat dengan tujuan melakukan hubungan badan dengan korban. Tidak adanya sikap berontak dari NL dipandang hakim bukan menunjukkan ketiadaan perlawanan/penolakan dari korban. Ancaman MT sudah menunjukkan bahwa NL berada di bawah ancaman sehingga tidak mempunyai kuasa untuk menolak permintaan pelaku.

Pertimbangan tersebut jelas mengutamakan keadaan anak yang pada dasarnya tidak memiliki tenaga sekuat orang dewasa sehingga hakim telah mengakomodasi nilai kesusilaan dalam hal ini kepentingan anak yang sangat dijunjung tinggi masyarakat Madura, terlebih anak perempuan yang dianggap 
sebagai milik berharga keluarga. Penemuan hukum progresif memberikan jembatan yang sangat tepat terhadap problematika hukum dan keadilan yang sering kali dipertentangkan. Pertimbangan putusan hakim menjadi dasar argumentasi yang sangat menentukan bagi terwujudnya penegakan hukum. Prinsip progresifitas menempatkan penemuan hukum yang dilakukan oleh hakim sebagai bagian dari cara penegakan hukum yang represif sekaligus kuratif. ${ }^{33}$ Dikatakan represif karena langsung dikenakan kepada pelaku sedangkan kuratif mengingat dampak dari putusan tersebut menjadi pelajaran kepada masyarakat akan tatanan hukum yang baik dan berkeadilan. Semua hakim PN Bangkalan mengatakan bahwa penemuan hukum progresif lebih mendasarkan diri pada kebutuhan masyarakat luas. Artinya tanpa meninggalkan kepastian hukum yang dijadikan dasar berpijak, hakim diajak untuk berpikir dan ikut merasakan keadilan yang berlaku di masyarakat.

Pemahaman yang baik terhadap penemuan hukum progresif tersebut ternyata berbanding terbalik dengan pengakuan hakim PN Bangkalan dalam menggunakan penemuan hukum progresif. $75 \%$ Hakim PN Bangkalan mengaku tidak pernah menggunakan metode penemuan hukum progresif dengan alasan ketentuan hukum yang ada selama ini sudah sangat jelas memberikan pengaturan. Hanya $25 \%$ hakim PN Bangkalan menyatakan sering menggunakan penemuan hukum progresif. Berdasarkan data tersebut, pemahaman penemuan hukum progresif masih dalam tataran teori saja padahal sudah dilakukan setiap kali menangani perkara kesusilaan. Akibatnya sudah dapat dipastikan, pertimbangan hakim pun pertama-tama berorientasi pada terpenuhi atau tidaknya unsur perbuatan yang ada dalam rumusan ketentuan hukum pidana. Peran hukum adat sebagai salah satu dasar pertimbangan putusan pun cenderung terabaikan.

Penting bagi seorang hakim untuk melakukan pemahaman secara mendalam terhadap nilai-nilai hukum yang hidup dan rasa keadilan masyarakat. Data yang diperoleh dari hakim PN Bangkalan ternyata menunjukkan $75 \%$ sering melakukan penggalian terhadap nilai-nilai hukum yang berlaku di masyarakat ketika menghadapi perkara kesusilaan, sisanya 25\% tidak melakukan sama sekali. Melihat banyaknya hakim PN Bangkalan yang melakukan penggalian nilai-nilai hukum atas Perkara kesusilaan menunjukkan adanya pemahaman yang komprehensif dalam diri hakim akan pentingnya penggalian atau setidaknya pengetahuan terhadap nilai-nilai kesusilaan yang berlaku di masyarakat.

Sebuah perkara yang diputus Pengadilan Negeri Bangkalan Nomor 07/Pid.B.An/2009/PN.Bkl. Tanggal 23 Juni 2011 justru menunjukkan hal yang sangat berkebalikan dibandingkan ketiga contoh Pertimbangan Hakim dalam Putusan yang dijadikan kajian penelitian. SU mengajak $\mathrm{HH}$ yang masih berusia 4 tahun untuk bermain burung merpati di sebuah bukit namun SU justru menggunakan kesempatan ini untuk mengajak $\mathrm{HH}$ melakukan persetubuhan walaupun ditolak oleh $\mathrm{HH}$. SU segera melucuti pakaian dan celana dalam $\mathrm{HH}$

33 Ismiyanto Heru Permana, Penegakan Hukum Di Era Reformasi, dalam Jurnal Dinamika Hukum, Tahun ke-2 No. 1 Januari 2002, hal. 91-93. 
dan melakukan penetrasi ke dalam alat kelamin HH. Korban pun merasa kesakitan sehingga membuat SU mencabut alat kelaminnya dan menggunakan tangannya pada alat kelamin HH. Dakwaan Primer Jaksa Penuntut Umum dinyatakan tidak terbukti karena hakim menilai SU tidak melakukan persetubuhan namun melakukan percabulan. Penilaian hakim tersebut justru merugikan kepentingan anak yang telah mengalami perkosaan yang terbukti dalam hasil visum et repertum terdapat robeknya selaput dara korban. Pemahaman hakim lebih terfokus pada tidak adanya ancaman kekerasan yang dilakukan oleh terdakwa untuk melakukan persetubuhan padahal jika dilihat dengan seksama justru SU melakukan kekerasan dengan mendudukan korban secara paksa yang dilanjutkan dengan penetrasi alat kelaminnya sekalipun tidak mengeluarkan air mani di dalam alat kelamin HH. Pertimbangan hakim tersebut jelas sangat merugikan kepentingan anak terlebih tidak menunjukkan prinsip progresifitas hakim dalam menggali dan memahami nilai-nilai kesusilaan yang berlaku bagi masyarakat Madura.

Diakomodasikannya nilai-nilai kesusilaan yang berlaku dalam pertimbangan putusan hakim jelas memberikan dampak besar bagi diterimanya putusan tersebut oleh terdakwa sekaligus masyarakat. Pertimbangan yang melandaskan diri pada nilai-nilai kesusilaan yang hidup bagi pelaku (terdakwa) sangat penting untuk memberikan edukasi sekaligus pembinaan yang tepat bagi tujuan pemasyarakatan. Bagi masyarakat sendiri digunakannya nilai-nilai kesusilaan jelas diterima dengan baik dan mendapatkan dukungan dari masyarakat. Sedangka bagi lembaga pengadilan hal tersebut memberikan kontribusi positif bagi lembaga pengadilan sebagai lembaga yang memberikan penegakan hukum.

\section{Simpulan}

Hasil penelitian ini menunjukkan bahwa norma kesusilaan sudah dijadikan dasar dalam menangani perkara kesusilaan yang terjadi di masyarakat Bangkalan Madura meskipun sudah ada ketentuan khusus yang mengatur perkara itu. Hal tersebut menunjukkan hakim Pengadilan Negeri Bangkalan telah melakukan penemuan hukum secara progresif dan tidak berpaku pada ketentuan hukum saja.

Pertimbangan putusan perkara kesusilaan yang dilakukan oleh Hakim Pengadilan Negeri Bangkalan telah menyerap nilai-nilai kesusilaan yang berlaku dalam masyarakat Bangkalan. Nilai-nilai tersebut bukan hanya dijadikan bahan pertimbangan dalam menentukan berat ringannya sanksi pidana akan tetapi pada pertimbangan atas substansi perkara kesusilaan yang diperiksa. Alhasil, putusan perkara kesusilaan tersebut dapat diterima oleh semua pihak termasuk masyarakat sebagai hukum yang hidup. 


\section{Daftar Pustaka}

\section{Buku}

Abdullah, MH. Said. Menuju Madura Moderen Tanpa Kehilangan Identitas, Jakarta: Taman Pustaka-SaidAbdullah Institute, 2011.

Rahardjo, Satjipto. Membedah Hukum Progresif, Jakarta: Kompas, 2007.

Rifai, Ahmad. Penemuan Hukum oleh Hakim dalam Perspektif Hukum Progresif, Jakarta: Sinar Grafika, 2010.

Wiyata, Latief. Carok: Konflik Kekerasan dan Harga Diri Orang Madura, Yogyakarta: LKiS, 2006.

\section{Artikel Jurnal}

Arto, A. Mukti. XXV (296) Juli 2010, "Putusan yang Berkualitas Mahkota bagi Hakim Mutiara bagi Pencari Keadilan" dalam Varia Peradilan, Tahun ke XXV No. 296: 21-34.

Butarbutar, Elisabeth Nurhaini. "Kebebasan Hakim Perdata dalam Penemuan Hukum dan Antinomi dalam Penerapannya", dalam Jurnal Mimbar Hukum,Tahun ke-23 No.1 Februari 2011: 61-76.

Christianto, Hwian. "Pembaharuan Makna Asas Legalitas", dalam Jurnal Hukum dan Pembangunan, Tahun ke-39 No. 3 Juli-September 2009: 347-375.

. "Norma Kesusilaan Sebagai Batasan Pornografi", dalam Jurnal Hukum dan Pembangunan, Tahun 40 No. 1 Januari-Maret 2010: 23-51.

"Batasan dan Perkembangan Penafsiran Ekstensif", dalam Jurnal Pamator, Tahun ke-3 No. 2 Oktober 2010, hal. 101-113

"Penafsiran Hukum Progresif dalam Perkara Pidana", dalam Jurnal Mimbar Hukum, Tahun ke-23 No.3 Oktober 2011, hal. 479-500

Fanani, Ahmad Zaenal. "Hermeneutika Hukum sebagai Metode Penemuan Hukum dalam Putusan Hakim", dalam Varia Peradilan, Tahun XXV No. 297 Agustus 2010: 54-64.

Fauzan, H.M. "Pesan Keadilan di Balik Teks Hukum yang Terlupakan: Refleksi atas Kegelisahan Prof. Asikin", dalam Varia Peradilan, Tahun ke-XXVI No. 299 Oktober 2010: 30- 45.

Hiarej, Eddy O.S. "Pemikiran Remmelinjk mengenai Asas Legalitas" di dalam Jurnal Jentera: 127. 
Ichsan, Muchamad. "Landasan Kebijakan Legislatif Pembangunan Hukum Pidana Indonesia", dalam Jurnal Ilmu Hukum, Tahun ke-16 No. IV April-Juni 2007, Tahun ke-10 No.1 Maret 2007: 103-122.

Koro, H.M. Abdi. "Penguasaan Hukum Formal dan Materiil Wajib Dimiliki untuk Pengembangan Kemampuan Hakim (Mastery of Legal Formal and Material Must Be Owned for the Development of the Ability of Judges)", dalam Varia Peradilan, Tahun ke-XXVII No. 319 Juni 2012: 41-531.

Manan, Bagir. "Beberapa Catatan tentang Penafsiran", dalam Varia Peradilan, Tahun ke-XXIV No. 285 Agustus 2009: 5-14.

Muchsin. "Tindak Pidana Pornografi menurut Undang-Undang Nomor 44 Tahun 2008", dalam Varia Peradilan, Tahun ke-XXIV No. 280 Maret 2009: 12-23.

Soemarsono, Maleha. "Negara Hukum Indonesia ditinjau dari Sudut Teori Tujuan Negara", dalam Jurnal Hukum dan Pembangunan, Tahun ke-37 No. 2 April-Juni 2007: 306-311.

Sudjito."Chaos Theory of Law: Penjelasan atas Keteraturan dan Ketidakteraturan dalam Hukum", dalam Jurnal Mimbar Hukum, Tahun ke-18 No. 2 Juni 2006, hal. 159-175

Sundari, E. “Aspek Ilmiah Metode Penemuan Hukum”, dalam Jurnal Justitia Et Pax, Tahun ke-27 No.1 Juni 2007: 43-60.

"Manfaat Mempelajari Teori Hukum", dalam Jurnal Justitia Et Pax, Tahun ke-27 No.2 Desember 2007: 171-182.

Tumpa, Harifin A. "Apa yang Diharapkan Masyarakat dari Seorang Hakim", Varia Peradilan, Tahun ke-XXV No. 298 September 2010: 6.

Permana, Ismiyanto Heru. "Penegakan Hukum Di Era Reformasi", dalam Jurnal Dinamika Hukum, Tahun ke-2 No.1 Januari 2002: 91-96.

Sidharta, B. Arief. "Struktur Ilmu Hukum Indonesia", dalam Jurnal Refleksi Hukum, Tahun ke- (tanpa nomor), Oktober 2008: 112-145.

Wibowo, Suliantoro, B. "Dialektika Hukum dan Agama dalam Pembangunan Hukum Nasional di Indonesia: Kajian Moral Politik Hukum", dalam Jurnal Justitia Et Pax, Tahun ke-27 No.1 Juni 2007: 33-42.

Witanto, D.Y. 'Konsepsi 'Local Wisdom' dalam Upaya Pembentukan Kesadaran Hukum", dalam Varia Peradilan, Tahun ke-XXVII No.314 Januari 2012: 71-79.

\section{Sumber lain}

Hwian Christianto, Penelitian, "Norma Kesusilaan sebagai Dasar Penemuan Hukum Progresif dalam Pertimbangan Putusan Hakim Pengadilan Negeri Bangkalan Madura", Universitas Surabaya, 2012. 